\title{
Sintese van silikonkarbied in 'n mikrogolfplasma
}

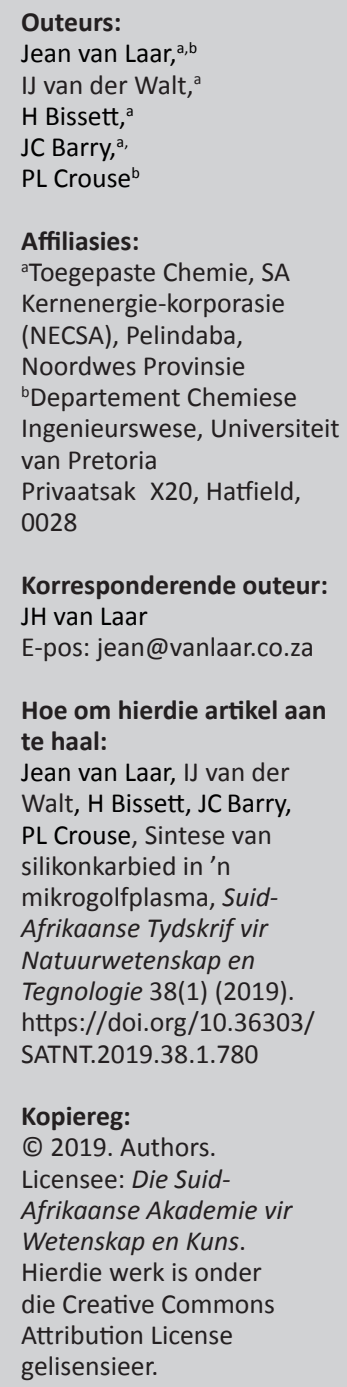

Korresponderende outeur: JH van Laar

E-pos: jean@vanlaar.co.za

Hoe om hierdie artikel aan te haal:

Jean van Laar, IJ van der

Walt, H Bissett, JC Barry,

PL Crouse, Sintese van

silikonkarbied in 'n

mikrogolfplasma, Suid-

Afrikaanse Tydskrif vir

Natuurwetenskap en

Tegnologie 38(1) (2019).

https://doi.org/10.36303/

SATNT.2019.38.1.780

\section{Kopiereg:}

(C) 2019. Authors.

Licensee: Die Suid-

Afrikaanse Akademie vir

Wetenskap en Kuns.

Hierdie werk is onder

die Creative Commons

Attribution License

gelisensieer.

\begin{abstract}
Synthesis of silicon carbide in a microwave plasma: The mechanical properties of silicon carbide $(\mathrm{SiC})$ favour its application in tristructural-isotropic fuel. In this study, $\mathrm{SiC}$ was deposited onto alumina particles in a microwave plasma-assisted spouted-bed reactor. Results indicate that optimal conditions for good-quality crystalline layers require high enthalpies and pressures, at the cost of lower deposition rates.
\end{abstract}

Die fisiese en meganiese eienskappe van silikonkarbied ( $\mathrm{SiC}$ ) maak dit geskik vir gebruik in hoë-drywing- en hoë-frekwensie-elektronika, sowel as in ander hoë-temperatuurtegnologieë. Hierdie keramiek word tans ook oorweeg vir kernafval-immobilisasie en as boumateriaal in die kernbedryf as gevolg van sy uitmuntende meganiese stabilitiet tydens bestraling. Hierdie gedrag is'n bydraende faktor by die gebruik daarvan in tristrukturele-isotropiese kernbrandstof (TRISO-brandstof). Huidige metodes vir die produksie van TRISO-brandstof behels chemiese dampdeponering in 'n sweefbedoond. Hierdie bewese tegnologie benodig egter hoë energieinsette om die verlangde temperature, $>1500{ }^{\circ} \mathrm{C}$, te bereik wat krystallyne SiC oplewer. Verskeie tegnologië word tans ondersoek wat moontlik hierdie tekortkoming kan oorkom, insluitend die gebruik van mikrogolfplasmareaktors (MPRs). MPRs lewer belowende resultate vir die sintese van deklagies en bied verskeie voordele soos hoë massa-en hitte-oordragtempo's.

Tydens hierdie studie is silikonkarbieddeklagies suksesvol op aluminapartikels gedeponeer in 'n mikrogolfplasma-spuitbedreaktor. Metieltrichlorosilaan (MTS) het as voorloper gedien vir die $\mathrm{SiC}$ deponeringsproses, met argon as beide draer- en plasmagas. Die reaktor bestaan uit 'n deursigtige kwartsbuis wat loodreg binne 'n reghoekige aluminium golfgeleier geplaas is, en die golfgeleier is op sy beurt aan 'n magnetron gekoppel wat verantwoordelik is vir die opwek van mikrogolwe. Argon vloei deur die kwartsbuis en word deur die mikrogolwe geïoniseer en tot die plasmatoestand opgewek. 'n Grafietspuitstuk aan die onderkant van die buis help op sy beurt om die spuitaksie van die aluminapartikels in die buis te bewerkstellig, met 'n metaalrooster aan die bokant van die buis om te verhoed dat enige partikels verlore raak.

Die gekose prosesparameters vir hierdie studie was: entalpie; druk; en die waterstof-tot-MTS molêre verhouding ( $\left.\mathrm{H}_{2}: \mathrm{MTS}\right)$. Die eksperimentele ontwerp was 'n driedimensionele (3D) sentrale saamgestelde patroon. Die partikels is na elke eksperiment versamel en daarna gekarakteriseer met behulp van optiese mikroskopie, transmissie-elektronmikroskopie (TEM), skandeerelektronmikroskopie (SEM), X-straaldiffraksie (XRD), X-straalfoto-elektronspektroskopie (XPS), energiedispersiewe X-straal-analise (EDS), Fourier-transformasie-infrarooispektroskopie (FTIR) en termogravimetriese analise (TGA). Die resultate het onder andere gelei tot die daarstelling van 'n kleurkaart met 'n korrelerende morfologiekaart wat veranderinge aandui as funksie van twee van die parameters, naamlik entalpie en druk.

Die resultate het getoon dat die groeitempo van die deklagies tussen $50 \mu \mathrm{m} / \mathrm{h}$ en $140 \mu \mathrm{m} / \mathrm{h}$ varieer en die massa-deponeringstempo tussen $19.1 \mathrm{~g} /\left(\mathrm{h} \cdot \mathrm{m}^{2}\right)$ en $331 \mathrm{~g} /\left(\mathrm{h} \cdot \mathrm{m}^{2}\right)$. Deur die toepassing van reaksieoppervlakmetodologie en ontleding van variansie (ANOVA) het die studie 3D-oppervlakkontoerkrommes gelewer wat daarop dui dat druk die mees beduidende veranderlike is. Dit was ook duidelik uit hierdie krommes dat die optimale bedryfspunt vir SiC-deklagiedeponering bereik word by hoë entalpie $(\sim 5 \mathrm{MJ} / \mathrm{kg})$ en druk $(>-60 \mathrm{kPag}) \mathrm{met}$ redelike hoë $\mathrm{H}_{2}$ :MTS-verhoudings ( 5:1). Die kwaliteit van die deklagies (bv. die kristalliniteit, partikelgroottes en Si:C verhoudings) verbeter aansienlik by hierdie toestande, ten koste van 'n laer deponeringstempo.

Nota: 'n Seleksie van referaatopsommings: Studentesimposium in die Natuurwetenskappe, 25-26 Oktober 2018, SA Akademiegebou, Pretoria, Suid-Afrika. Gasredakteurs: Prof Rudi Pretorius (Departement Geografie, Universiteit van Suid-Afrika); Prof Chris Swanepoel (Departement Besluitkunde, Universiteit van Suid-Afrika); Me Andrea Lombard (Departement Geografie, Universiteit van Suid-Afrika) 